\title{
CHALLENGES OF TOURISM MARKETING IN NEPAL: GLOBAL AND REGIONAL PERSPECTIVE
}

\author{
Bagala Basnet ${ }^{*}$
}

\begin{abstract}
Tourism is very popular due to its growing importance in every sphere of human life. It is considered as a smokeless industry and has grown up very fast in the last few decades. It is a service industry and most sectors of it are labour intensive and require relatively short training for most of the jobs. It is supported by hotels, airlines, travel and tour and handicrafts industries. The study of marketing helps to fulfill the needs and wants of the consumer or users in a better way. It also helps the service providers to earn sufficient profit through customer satisfaction. In the past, product oriented marketing has helped to increase visitor's arrival. But in recent years, attention has been shifted from product destination to potential destination visitors. Nepal is a land of natural wonders and cultural mosaic. This small country in South Asia has unlimited possibilities of promoting various kinds of tourism. The only thing lacking is a will and enthusiasm on our part. Looking at the global trend, the competition towards getting the highest share of ever growing tourism industry, it is becoming fiercer and challenging. Now the time has come to improve the socio-economic condition of Nepal through the sustainable development of tourism and categorizing Nepal as one of the best destinations in the world.
\end{abstract}

\section{INTRODUCTION}

Tourism is regarded as one of the world's fastest growing industries. It has been playing a pivotal role in the socio-economic development of the most developed as well as developing countries of the world. Tourism is as old as human civilization and it is natural for human being to travel to different places to satisfy their desires. It is a well-known fact that as long as the inherent sense of curiosity and adventure dwells in the heart of every human being the desire to travel in order to see new sights and experience new things and to live under different environment will always grow (Pandey 2008).

In old age travel has been looked at as a journey, pilgrimage and adventure, while in the modern world, travel has become 'tourism'. It is an activity provided by an increasing number of personnel involving directly and indirectly in the travel sector to satisfy the need and desire of the visitors. It is very difficult to define modern tourism because it has multiplier effect in the life of the people, society, nation and world as a whole (Basnet 2009). Tourism is unique and it involves industry without smoke, education without classroom, integration without legislation and diplomacy without formality (Ghosh 2000). However, in general tourism moves people from one region to another, whether it is within one's country or other countries, for various purposes (Mohanty 1992

"Associate Professor,Saraswati Multiple Campus,Tribhuvan University, Kathmandu, Nepal 
and Singh. 2000). It may be said to be a 'dream industry' which helps to realize a dream of fantasy in the mind of the tourists (Dhakal 2006).

\section{GENERAL BACKGROUND: NEPALESE PERSPECTIVE}

Nepal ranks among the least-developed countries in Asian and Pacific Region with per capita income of US\$ 468 (CBS 2008). Due to its population growth rate $(2.25 \%, 2001, \mathrm{CBS})$, landlocked position, low rate of domestic saving (11.21\%, 2007/08 CBS), adverse balance of payment (Rs-162.67 billion, 2007/08), more dependent on traditional agriculture system and poverty (31.0\%: NLSS-Economic Survey 2003/04) have created a greater challenge for country's economic development in the context of building New Nepal. Similarly, capital flight from Nepal is increasing to a large extent to India and overseas countries. The indigenous and foreign investors are reluctant to set up investment due to insecurity situation and social-conflict. However, the country has tremendous potentials for sustainable socio-economic growth. After water resource and remittance, the prospect for tourism is enormous. The main efforts of government as directed towards identifying and mobilizing resources for balanced economic growth may be successful only through the sustainable development of tourism sector. Because it is an important instrument for promoting and managing the country's cultural, ecological and environmental heritage, generating a demand for goods and services through increased tourist arrivals and higher spending, increasing foreign exchange earnings and reeducating poverty by diversifying the benefits of tourism throughout the country. Realizing the current Three Years Interim Plan -2008-2010 (Pradhan and Grandon 2008).

Nepal is known as important tourist destination in the world with its natural beauty and cultural heritages, mystique nature and different kinds of flora and fauna, birds and animals, eye soothing scenery and majestic snow clad mountain favoring the visitors in all seasons. All these have continued to attract a large number of visitors of the world (Basnet 2009).

Tourism in Nepal is very young as Nepal opened its door for tourism only during the early fifties. The early visitors to the country were explorers and mountaineers and they were specially attracted by its challenging mountains. However, there are certain challenges for the development of tourism. Owing to the political instability and lack of security, a great hesitation has been created in the mind of the tourists. Similarly, though the development of roads and airlines are great pillars for the development of tourism, facility of road network and airline services are not sufficient to meet the growing demands of the international visitors. Apart from this, owing to the pollution of environment, lack of provision for safe drinking water, sanitation and heavy load shedding, have created problems for the development of tourism in Nepal. Similarly, due to the lack of diversification of tourism products, all the facilities are centrally located in Kathmandu valley and Kathmandu has been reflected as he most popular destination for the tourists, followed by Pokhara, Chitwan, Patan, Bhaktapur, Lumbini and some other trekking trails. It is also known that Nepal is a famous destination for holiday and pleasure; however arrangements of recreational facilities are very limited for all kinds of visitors. As per the information provided by 
Ministry of Culture, Tourism and Civil Aviation (MoCTCA 2008), the average length of stay has not increased more than 13 days. Survey shows that holiday and pleasure groups hardly spent three or four nights in Nepal. As we know tourism is an ever changing and never ending process and it requires clear vision regarding what to sell and how to make the tourism products competitive in the international market. However, due to the failure in implementing the plan, limited promotional activities in international level and inadequate quality control mechanism Nepal has not been able to earn sufficient benefits from tourism at present.

\section{OBJECTIVES}

The generic objective of this study is to examine the status of tourism service marketing in Nepal.

The specific objectives of this study are to introduce the need of tourism service marketing, to access the trend of international, regional and national level tourism and to portray the customer satisfaction and the quality of tourism services in Nepal.

\section{METHODOLOGY}

This study is entirely based on descriptive as well as survey research design. In this study, both primary and secondary data are used and different techniques are followed for the collection of the necessary information. Primary data are collected through field survey using different data collection methods such as questionnaire and interview with and 428 tourists visiting Nepal of different age groups during the period 2006. Both open and closed-ended questionnaires are prepared to address the tourists and interviewed. Since the objectives of this study are to portray the status of tourism service marketing in Nepal, to determine the perception of tourist regarding customer satisfaction and quality of services. Most of the secondary data employed in this study are obtained from government, semi-government and private officers. Apart from this, the secondary data are collected from various books, journals and unpublished research carried out by different scholars to study the trend of international, regional and national tourism and to address tourism scenario marketing scenario of Nepal. Similarly, primary and secondary data are edited, tabulated and interpreted using appropriate statistical tools.

\section{TOURISM SCENARIO: NEPAL}

Since the inception tourism in the 1950s, it has been playing a significant role for the development of Nepalese economy. The topographical situation restricts industrial settlements, difficult to extract natural resources because of low finance, and inability to satisfy the growing demands of food due to limited agricultural cultivation areas. In such a situation, tourism is one of the economic sources with a future characteristic. Today it plays the role of the biggest foreign exchange earner as well as the economic sector with the biggest dependence factor. 
Table 1. Status of Tourism in Nepal (1990-2008)

\begin{tabular}{|c|c|c|c|c|c|c|c|c|c|}
\hline Year & $\begin{array}{c}\text { Tourist } \\
\text { Arrivals } \\
\text { in } \\
\text { Thousand }\end{array}$ & $\begin{array}{c}\text { \% } \\
\text { change }\end{array}$ & Index & $\begin{array}{c}\text { Receipts } \\
\text { \$Million }\end{array}$ & $\begin{array}{c}\text { \% } \\
\text { Change }\end{array}$ & Index & $\begin{array}{c}\text { Average } \\
\text { income per } \\
\text { visitor per } \\
\text { day }\end{array}$ & $\begin{array}{c}\text { Average } \\
\text { length of } \\
\text { stay }\end{array}$ & $\begin{array}{c}\text { Contri- } \\
\text { bution } \\
\text { of GDP }\end{array}$ \\
\hline 1990 & 254.8 & - & 100 & 63.7 & - & 100 & 27.2 & 12.0 & 32 \\
\hline 2000 & 4636 & 84.1 & 184 & 166.8 & 161.8 & 261.8 & 38.2 & 11.8 & 2.9 \\
\hline 2002 & 275.4 & -40.7 & 109.0 & 106.8 & -35.9 & 167.6 & 64.8 & 7.9 & 2.6 \\
\hline 2004 & 385.2 & 3.6 & 1526 & 179.9 & 68.4 & 282.3 & 45.1 & 13.5 & 1.8 \\
\hline 2006 & 383.9 & -03 & 152.2 & 162.7 & -9.6 & 2553 & 55.0 & 10.2 & 1.4 \\
\hline 2007 & 526.7 & 36.6 & 208.8 & 230.6 & 41.7 & 361.8 & 45.0 & 11.9 & 2.3 \\
\hline 2008 & 500.2 & -5.1 & 198.2 & 351.9 & 52.6 & 552.1 & 73.0 & 11.7 & 2.6 \\
\hline
\end{tabular}

Source: Nepal Tourism Statistics - 2006, 2007 and 2008 (MOCTCA).

According to the data shown in table-1, international tourist arrival in Nepal have gone up from 252 thousand in 1990 to 256 thousand in 2007 and owing to the unrest situation in Tarai, load shedding, high rate of road accident, and the effects of recession, the number of tourist arrivals slightly fell to 500 thousand in the latter year 2008 by $-5.1 \%$. While with the massive efforts of Nepal Tourism Board and along with the initiation of other private sector organizations, the figures of arrival went up by $1.8 \%$ reaching 509 thousand at the end of 2009. The study shows that there is a direct relationship between tourist arrival and the economic benefits to the host country. The contribution of tourist expenditure to national economy of Nepal is crucial as income and employment opportunities in other sectors are scare (Bhandari 2010). The figures table 1 show that in Nepal the receipts from international tourism is reported to have gone up from US dollar 63.7 million in 1990 to 351.9 million US dollar in 2008 with some fluctuation over the years. The receipts in the latter year witnessed a significant increase of 52.6\% compared to 2007. Similarly, average income per visitor per day is also found to have increased significantly form US dollar 27.2 in 1990 to US dollar 73.0 in 2008 with some fluctuation over the years. However, owing to the lack of recreational facilities, political disturbances and world wide economic crisis, average length of stay of international visitors was found to have decreased from 11.9 days in 2007 to 11.7 days in 2008. On the other hand, the contribution of GDP from this sector goes by 2.6\% in 2008/09 from 2.3\% in 2007/08 (Nepal Tourism Statistics 2008). It shows that the economic impact of tourism can be linked up with its multiplier effects.

\section{TOURISM SCENARIO: GLOBAL}

Tourism is a global phenomenon that is increasing day by day and it has grown tremendously in the last couple of decades (Sherpa 2005). It has been considered as a major product of modernization and globalization. The substantial growth of the tourism activity clearly marks tourism as one of the most remarkable economic and social phenomena of the past century. 
Table 2. Status of International Tourist Flow and Tourism Receipts (1990-2008)

\begin{tabular}{|c|c|c|c|c|}
\hline Year & $\begin{array}{c}\text { Tourist } \\
\text { Arrival in } \\
\text { Million }\end{array}$ & \% change & $\begin{array}{c}\text { Tourist } \\
\text { Receipt in US } \\
\text { \$ in Billion }\end{array}$ & \% Change \\
\hline 1990 & 438 & - & 264 & - \\
\hline 1995 & 534 & 21.9 & 405 & 534 \\
\hline 2000 & 684 & 28.1 & 475 & 17.3 \\
\hline 2005 & 804 & 17.5 & 680 & 43.2 \\
\hline 2006 & 853 & 6.1 & 745 & 9.6 \\
\hline 2007 & 904 & 6.0 & 856 & 15.0 \\
\hline 2008 & 922 & 2.0 & 944 & 10.2 \\
\hline
\end{tabular}

Source: WTO (UNWTO) - Tourism Highlight 2009.

The figure displayed in table 1 indicates that international tourists' arrivals have continued to increase from 438 million in 1990 to 992 million in 2008. It is a witness of the international tourists arrival found increased moderately high since 2005 to 2007 but the growth trend slowed by 2.0 per cent over the year 2008 as compared to the previous year. In the case of receipts, this shows an upward trend from US\$ 264 billion in 1990 to US\$ 944 billion in 2008. However, the percentage of growth rate in 2008 shows a downward trend by $10.2 \%$ compared to the growth trend $(15.0 \%)$ of preceding year 2007 . This clearly indicates global recession impact upon the travel plans of the people around the world and has forced them to deduct long haul trip. According to the UNWTO (WTO 2009), the growth in international tourist arrival has slowed drastically worldwide, under the influence of an extremely volatile and unfavorable global economy-due the factors such as the credit crunch, the widening financial crisis, commodity and oil price rises, and massive exchange rate fluctuations. Similarly, it has also affected the spending capacity of international tourists around the world. As a result, the receipts from international tourism did not show progress. It was also noticed that tourism trend of Nepal is also affected by the world tourists arrival.

\section{TOURISM SCENARIO: REGIONAL}

The development of regional tourism is very slow. It also contributes in sustaining the movement of visitors to each other's country. Hence, elimination of cumbersome practices and easing the travel formalities have got attention among regional networks (Dhakal 2008). 
Table 3. Status of Tourism in Selected South Asian Countries (2000-2008)

\begin{tabular}{|c|c|c|c|c|c|c|}
\hline \multirow{2}{*}{ Country } & \multicolumn{5}{|c|}{ International Tourist Arrivals in (Thousand) } & \multirow{2}{*}{$\begin{array}{c}\% \\
\text { Change } \\
2007 / 08\end{array}$} \\
\hline & 2000 & 2004 & 2006 & 2007 & 2008 & \\
\hline Bangladesh & 199 & 271 & 200 & 397 & 349 & -12 \\
\hline Bhutan & 8 & 9 & 17 & 21 & 27 & 28.6 \\
\hline India & 2649 & 3457 & 4430 & 5082 & 5367 & 5.6 \\
\hline Maldives & 467 & 617 & 602 & 676 & 683 & 1.0 \\
\hline Nepal & 464 & 385 & 384 & 527 & 500 & -5.1 \\
\hline Pakistan & 557 & 648 & 898 & 840 & 823 & -2.0 \\
\hline SriLanka & 400 & 566 & 560 & 949 & 438 & -11.3 \\
\hline
\end{tabular}

Source: UNWTO- Tourism Highlights - 2007, 2008, and 2009 Edition.

Table 3 highlights the summary of international tourist arrivals in selected South Asian countries from the years 2000 to 2008. It also exhibits that India has always been a top country in tourism sector in South Asia. The total number of international tourist arrival in India, reached 5367 thousand, up from 5082 thousand in 2007, representing a growth of 5.6\%. After India, Pakistan witnessed the second position with tourist arrival reaching 823 thousand followed by Maldives (683 thousand), Nepal (500 thousand), Sri-Lanka (438 thousand), Bangladesh (349 thousand) and Bhutan (27 thousand). The figure also exhibits that Bhutan experienced a significant rise in the growth pace of international tourist arrivals in 2008 compared to India and Maldives. While, Bangladesh (-12\%), Sri-Lanka (-11.3\%), Nepal (-5.0\%) and Pakistan (-2.0\%) experienced a significant drop in arrivals in 2008 compared to 2007 which may be attributed to visitor' fear due to political instability and security concern inside the country as well as global economic environment.

\section{REVIEW OF LITERATURE}

This section reviews the need of marketing in tourism and demarcates the differences of marketing of tourism products and physical products.

\section{TOURISM MARKETING}

Tourism is a service sector and it has distinct characteristics. The activities of tourism are service in nature i.e. recreational experience and hospitality and it is highly intangible and perishable in nature. Tourism products have unique features that differentiate from the physical products and it is more difficult to market than tangible products (Jaishi 2008). Instead of taking the product to the customers, the customers most travel to the product i.e. area or destination (Bhattarai 2008). In the present day, marketing of tourism products and services has become one of the important as well as challenging jobs and for the success of these business activities. There is always a need for proper marketing system. The study of marketing helps not only to fulfill the needs and desires of the consumer in a better way than that of the competitors but it also helps the service providers to earn sufficient profit through customer care and satisfaction.

Bhatia (1997) emphasizes that tourism as one part of service and it has occupied a vital place in business studies all over the world. Bukart and Medlick 
(1979) and Jha (2003) opine that tourism marketing activities are systematic and coordinated efforts excreted by National Tourism Organization (NTO) or the tourist enterprise on international, national and local levels to fulfil the satisfaction of tourist, groups and individuals in view of a sustained tourism growth. Though marketing in tourism is followed the same principles of general marketing but due to its some peculiar qualities in recent years, attention has been shifted from product oriented destination to potential visitors destination (Batra and Chawla, 2001).

In view of Baskota and Sharma (1998) and Tuladhar (2006) tourism marketing is so basic that it can be considered as a separate function. It is the whole business seen from the point of view of its final result that is from the customer's point of view and tourism planner must try to identify and understand the customers. Similarly, in views of Seaton Bennet (1996) marketing plays a crucial role in tourism because it is rare that the customer sees, feels, or tastes the products but he or she must travel to the destination. They differentiate tourism marketing from that of other forms of marketing because it must present an overall vision of the complete tourism product, including peripheral services from other sectors. Thus tourism marketing is useful to the tourism business entrepreneurs to earn sufficient income through customer care, employee's satisfaction as well as offering of quality goods and services to the tourists. It will also help the marketer to meet the standard and expectations of the customers. The study of tourism marketing will help the government to make plans and policy and implement rule and regulations for the sustainable development of tourism.

\section{TOURISM SERVICE: EMPIRICAL ANALYSIS}

Table 4. Rating of Visitor's opinion regarding different facilities and services of Tourism

\begin{tabular}{|c|c|c|c|c|c|c|c|c|}
\hline Quality of service & $\begin{array}{c}\text { Highly } \\
\text { satisfied }\end{array}$ & Satisfied & Fair & $\begin{array}{c}\text { Less } \\
\text { satisfied }\end{array}$ & Poor & Total & $\begin{array}{l}\text { Sum } \\
\text { of cf }\end{array}$ & $\begin{array}{c}\text { Ave- } \\
\text { rage } \\
\text { Mean }\end{array}$ \\
\hline Travel Agency & $\begin{array}{c}70 \\
(16.35 \%)\end{array}$ & $\begin{array}{c}150 \\
(35.05 \%)\end{array}$ & $\begin{array}{c}180 \\
(42 . .05)\end{array}$ & $\begin{array}{c}18 \\
(4.21 \%)\end{array}$ & $\begin{array}{c}10 \\
(2.34)\end{array}$ & $\begin{array}{c}428 \\
(100.00 \%)\end{array}$ & 1536 & 3.6 \\
\hline Tourist Guide & $\begin{array}{c}40 \\
(9.35 \%) \\
\end{array}$ & $\begin{array}{c}148 \\
(34.58 \%) \\
\end{array}$ & $\begin{array}{c}166 \\
(38.79 \%)\end{array}$ & $\begin{array}{c}48 \\
(11.21 \%) \\
\end{array}$ & $\begin{array}{c}26 \\
(6.07)\end{array}$ & $\begin{array}{c}428 \\
(100.00 \%)\end{array}$ & 1412 & 33 \\
\hline $\begin{array}{l}\text { Facility of } \\
\text { Accommodation }\end{array}$ & $\begin{array}{c}16 \\
(3.74 \%) \\
\end{array}$ & $\begin{array}{c}90 \\
(21.03 \%)\end{array}$ & $\begin{array}{c}192 \\
(44.86 \%) \\
\end{array}$ & $\begin{array}{c}100 \\
(23.36 \%)\end{array}$ & $\begin{array}{c}30 \\
(7.01)\end{array}$ & $\begin{array}{c}428 \\
(100.00 \%)\end{array}$ & 1246 & 2.9 \\
\hline Food and beverage & $\begin{array}{c}70 \\
(16.35 \%) \\
\end{array}$ & $\begin{array}{c}90 \\
(21.03 \%)\end{array}$ & $\begin{array}{c}180 \\
(42.05)\end{array}$ & $\begin{array}{c}80 \\
(18.89 \%) \\
\end{array}$ & $\begin{array}{c}8 \\
(1.86)\end{array}$ & $\begin{array}{c}428 \\
(100.00 \%)\end{array}$ & 1418 & 3.3 \\
\hline $\begin{array}{l}\text { Facility of } \\
\text { International Airlines }\end{array}$ & $\begin{array}{c}25 \\
(5.84 \%)\end{array}$ & $\begin{array}{c}40 \\
(9.35 \%) \\
\end{array}$ & $\begin{array}{c}100 \\
(23.36)\end{array}$ & $\begin{array}{c}153 \\
(35.75 \%) \\
\end{array}$ & $\begin{array}{c}110 \\
(25.07)\end{array}$ & $\begin{array}{c}428 \\
(100.00 \%)\end{array}$ & 1001 & 2.3 \\
\hline $\begin{array}{l}\text { Other Transportation } \\
\text { Facilities }\end{array}$ & $\begin{array}{c}30 \\
(7.01 \%) \\
\end{array}$ & $\begin{array}{c}50 \\
(11.68 \%) \\
\end{array}$ & $\begin{array}{c}120^{\prime} \\
(28.04 \%) \\
\end{array}$ & $\begin{array}{c}150 \\
(35.05 \%) \\
\end{array}$ & $\begin{array}{c}78 \\
(18.22) \\
\end{array}$ & $\begin{array}{c}428 \\
(100.00 \%)\end{array}$ & 1088 & 25 \\
\hline $\begin{array}{l}\text { Recreational } \\
\text { facilities }\end{array}$ & $\begin{array}{c}22 \\
(515 \%) \\
\end{array}$ & $\begin{array}{c}90 \\
(21.03 \%) \\
\end{array}$ & $\begin{array}{c}160 \\
(37.38 \%) \\
\end{array}$ & $\begin{array}{c}150 \\
(35.05 \%) \\
\end{array}$ & $\begin{array}{c}6 \\
(1.04) \\
\end{array}$ & $\begin{array}{c}428 \\
(100.00 \%) \\
\end{array}$ & 1256 & 29 \\
\hline $\begin{array}{l}\text { Pollution of } \\
\text { Environment }\end{array}$ & $\begin{array}{c}32 \\
(7.48 \%) \\
\end{array}$ & $\begin{array}{c}66 \\
(15.42 \%) \\
\end{array}$ & $\begin{array}{c}100 \\
(23.36 \%)\end{array}$ & $\begin{array}{c}120 \\
(28.04 \%) \\
\end{array}$ & $\begin{array}{c}110 \\
(25.70)\end{array}$ & $\begin{array}{c}428 \\
(100.00 \%)\end{array}$ & 1074 & 25 \\
\hline $\begin{array}{l}\text { Facility of } \\
\text { communication }\end{array}$ & $\begin{array}{c}30 \\
(7.01 \%)\end{array}$ & $\begin{array}{c}70 \\
(16.35 \%) \\
\end{array}$ & $\begin{array}{c}100 \\
(23.36 \%) \\
\end{array}$ & $\begin{array}{c}150 \\
(35.05)\end{array}$ & $\begin{array}{c}78 \\
(18.22) \\
\end{array}$ & $\begin{array}{c}428 \\
(100.00 \%)\end{array}$ & 1108 & 2.6 \\
\hline Peace and security & $\begin{array}{c}76 \\
(17.76 \%)\end{array}$ & $\begin{array}{c}64 \\
(14.95 \%)\end{array}$ & $\begin{array}{c}180 \\
(42.06 \%)\end{array}$ & $\begin{array}{c}100 \\
(23.36)\end{array}$ & $\begin{array}{c}8 \\
(1.87)\end{array}$ & $\begin{array}{c}428 \\
(100.00 \%)\end{array}$ & 1384 & 32 \\
\hline $\begin{array}{l}\text { Preservation of } \\
\text { tourist area }\end{array}$ & $\begin{array}{c}70 \\
(16.36 \%)\end{array}$ & $\begin{array}{c}90 \\
(21.03 \%)\end{array}$ & $\begin{array}{c}130 \\
(30.37 \%)\end{array}$ & $\begin{array}{c}120 \\
(28.04)\end{array}$ & $\begin{array}{c}18 \\
(4.21)\end{array}$ & $\begin{array}{c}428 \\
(100.00 \%)\end{array}$ & 1358 & 3.2 \\
\hline People & $\begin{array}{c}216 \\
(50.47 \%) \\
\end{array}$ & $\begin{array}{c}110 \\
(25.70) \\
\end{array}$ & $\begin{array}{c}80 \\
(18.69 \%) \\
\end{array}$ & $\begin{array}{c}22 \\
(5.14) \\
\end{array}$ & - & $\begin{array}{c}428 \\
(100.00 \%) \\
\end{array}$ & 1804 & 4.2 \\
\hline $\begin{array}{l}\text { Water supply and } \\
\text { electricity }\end{array}$ & $\begin{array}{c}25 \\
(5.84 \%)\end{array}$ & $\begin{array}{c}50 \\
(11.68 \%)\end{array}$ & $\begin{array}{c}123 \\
(28.74 \%) \\
\end{array}$ & $\begin{array}{c}120 \\
(28.04)\end{array}$ & $\begin{array}{c}11 \\
(25.70)\end{array}$ & $\begin{array}{c}428 \\
(100.00 \%)\end{array}$ & 1044 & 2.4 \\
\hline
\end{tabular}

Source: Field Survey 2006. 


\section{SURVEY FINDINGS}

In this study, an attempt has been made to access the tourism development and marketing on the basis of view and perceptions collected through the questionnaires and in-depth interviews with the tourists.

The role of travel agency and tourist guide is very important for the development of tourism. When asked to the respondents about the service of travel agencies and tourist guides, they rated mean score of 3.6 and 3.3 respectively. This shows that the respondents were moderately satisfied. Similarly, when the respondent have asked about the facility of accommodation and food and beverage served by hotels they showed lesser than mean satisfaction about the facility of accommodation with mean score of 2.9 which was lesser than the mean score (3.3) of food and beverage served. The study also noted that airline services as well as other transportation facilities are also equally important for the development of tourism. The response regarding the facility of international airline as well as other transportation, the respondent showed a very weak response rating 2.3 mean score in international airline and 2.5 in other transportations facility. Similarly, questions regarding the facility of recreations, peace and security and preservation of tourist area, the respondents were found moderately satisfied and showed an almost equal mean score of 2.9, 3.2, and 3.2 respectively. The response regarding the communication facility, environment pollution, safe drinking water and facility of electricity, was more upset with a mean score of 2.6, 2.5 and 2.4 respectively. Tourism being a labour intensive service industry, the respondents were found happy with the behavior of the people of Nepal and shows a highest mean score of 4.2.

\section{CONCLUSION AND RECOMMENDATIONS}

Tourism is the world's fastest growing industry. Being one of the hottest economic activities, it has affected almost every part of the world and Nepal is not an exception. Nepal is a least developed country with low per capita income, low rate of domestic saving and adverse balance of payments. However, tourism has been regarded as the most viable sector for the socio-economic development of the country. Nepal is a famous destination in the world with its natural and cultural heritages, flora and fauna, arts and architectures. Though it has immense potentialities of tourism development, owing to the lack of competent and trained manpower, lack of airline facilities and road network, lack of quality hotels in different parts of the country, limited facility of safe drinking water, supply of electricity, communication, and sanitation, pollution of environment, political instability and frequent sudden strikes and road blockage and road have caused negative experience in the minds of the international visitors. As a result, Nepal has not been able to sell tourism products adequately in the international market and generate adequate income to the nation compared to other neighbouring countries of Asia. In this situation, the study suggests certain suggestions. As tourism is the fragile industry, which takes unnoticed turns immediately after the occurrence of positive or negative incidents in any country or neighborhood, all political parties should concentrate their mind for the development of nation rather than criticizing each other. Similarly, to achieve the benefits from tourism 
to the disadvantaged and village level, new tourism products should be explored and diversified and infrastructure i.e. different grade hotels, lodges, and restaurants, roads and airline facilities should be developed. The quality of service of Nepal Airline Corporation should be developed and private airlines companies of Nepal should be encouraged to operate international flights in the tourist generating markets of the world.

Likewise quality control mechanism should be developed to check the quality of services and food beverage of hotels, lodges and restaurants. It is also noticed that the highest numbers of visitors come to Nepal every year for holiday and pleasure but recreational facilities especially for children and elderly people are very limited. So the study suggests that recreations such as fun park, museum, library, day care, sports, summer camp and winter camp should be organized to attract the child visitors and facility of rest house, home stay, deluxe van and hotels and treatment through natural therapy should be developed for the elderly visitors. The study shows that a large number of visitors are less satisfied with the pollution of environment. In the like manner a clean, green city environment is very important to increase the length of stay of visitors. A national level campaign is also required for better waste management in the major tourist destination to develop a culture of hygiene and make Tourism Year 2011 more successful.

The study also shows dissatisfaction regarding the preservation and maintenance of world heritage sites of Nepal i.e. Hanuman Dhoka Durbar Square, Swayambhu Nath Stupa and Boudha Nath Stupa of Kathmandu due to the lack of commitment on preservation and maintenance. These places are deteriorating day by day from men and animal. This study suggests protecting these areas with great care and concern by the concerned bodies. Although the people of Nepal are helpful, smiling face and honest to the visitors, but they lack some civic sense to some extent while crossing roads, plying vehicles and throwing garbage on the roads where people pass by. The study, thus suggests to control such activites immediately by the concerned bodies by regulating strict rules and regulations.

To overcome the dissatisfaction of tourists regarding the service of tourist guides the study suggests tourist guides with adequate experience and knowledge about different place, religion, art and architecture and treasures of our country along with a good command of different languages to solve the different problems related to language.

\section{WORKS CITED}

Anju, M. and B.S. Bhatia. 1996. Marketing of Tourism Services- Annual Publication Pvt. Ltd., New Delhi.

Basnet, B., 2009, Tourism Service Marketing in Nepal. Ph.D, Trhvhuvan University, Kathmandu.

Batra, G.S. and A.S. Chawla, 2001, Tourism Management, Deep and Deep Publications Pvt. Ltd., West Patel Nagar, Delhi.

Bhandari, K.R. 2010. Nepal Tourism year 2011 and beyond - Souvenir 2010 NATHAM 
Bhattarai, T.N. 2008. Tourism Management. Januka Publication, Min Bhavan Campus, Road Kathmandu. Nepal.

Burkart, A.J and S. Medlik. 1974. Tourism: Past, present and Future, London,

Dhakal, D.P. 2008. Trend of Tourism Development: Global, Regional, and National, Sunlight Publication, Students Book, Kirtipur, pages 145

Ghosh, B. 2000. Toursim and Travel Management. $2^{\text {nd }}$ Ed., Vikas Publishing House.

Habler, P. 2006. The Golgen Age will be back in Nepal.

Jha. S.M. 2003. Service Marketing, $2^{\text {nd }}$ Ed., Himalayan Publishing House, Delhi.

Ministry of Culture, Tourism and Civil Aviation/ Nepal Tourism Statistics (Different Years), Kathmandu.

Ministry of Finance. Economic Survey 2008/09. GON, Ministry of Finance Singh Durbar.

Mohanty, P. 1992. Hotel Industry and Tourism in India. Doctoral Dissertation, Publishing House, New Delhi.

National Planning Commission. 2009. Nepal in Figures, 2009. GON, National Planning Commission Secretariat Central, Bureau of Statistics, Kathmandu.

Nepal Rastra Bank. 2009. Macro Economic Indicators of Nepal.

Nepal Tourism Board. 2010 (2066/67). Annual Operational Plan . Kathmandu.

Pandey, R.J. 2008. Rural Tourism Development Phenomenon and Marketing Concepts. Sunlight Publication, Students Book, Kirtipur, pages 175.

Pradhan, B. and R.Grandn. 2008. Ecotourism: Concept and Issues. Sunlight Publication, Students Book, Kirtipur.

Ritchiem, Brent J.R. and C.K. Goldner (editor). 1984. Travel Tourism and Hospitality. Toronoto, Research, John Willy and Sons.

Shakya, K. 2008. Tourism-Yesterday, Today and Tomorrow. Sunlight Publication, Students Book, Kirtipur, pages 31.

Shrestha C.L. 2008. State of Tourism in Nepal - An Overview. Sunlight Publication, Student Book, Kirtipur, pages 249.

Tewari, S.P. 1994. The Tourism Dimension, Atma Ram and Sons, Delhi.

Tuladhar, G.R. 2006. Success/Failure of NTO’s Marketing, NTTR. Oct. 30-Nov., Vol. IX, Issue No. 49.

WTO (UNWTO). Tourism Highlight. 2006, Edition, UNWTO.

WTO (UNWTO). Tourism Highlight. 2007, Edition, UNWTO.

WTO (UNWTO). Tourism Highlight. 2008, Edition, UNWTO.

WTO (UNWTO). Tourism Highlight. 2009, Edition, UNWTO.

www.Welcomenepal.com

www.google.com

www.tourism.gov.np 